\title{
4. CONSOLIDATION AND PERMEABILITY CHARACTERISTICS OF SEDIMENTS FROM DEEP SEA DRILLING PROJECT LEG 93, SITES 603 AND 604 ${ }^{1}$
}

\author{
Mark W. Johns, Department of Oceanography, Texas A\&M University ${ }^{2}$
}

\begin{abstract}
The consolidation-permeability characteristics and index properties of seven sediment samples from Deep Sea Drilling Project Leg 93, Sites 603 and 604, were studied in an effort to gain an understanding of the processes acting on contourite sediments. Three hemipelagic silty clay contourite sediment samples collected with the hydraulic piston corer (HPC) from depths between 47 and $83 \mathrm{~m}$ were found to be overconsolidated. X-radiographs indicated these samples to be relatively undisturbed. Coring and degassing disturbance has produced an apparent state of underconsolidation for one near-surface and two deeper samples from Site 603. Permeability values ranged between $2.7 \times 10^{-7}$ and $6.4 \times$ $10^{-8} \mathrm{~cm} / \mathrm{s}$. The one sample tested from Site 604 at a depth of $4.42 \mathrm{~m}$ was found to be overconsolidated. The permeability value for this sample, $1.4 \times 10^{-4} \mathrm{~cm} / \mathrm{s}$, was considerably higher than those measured at Site 603 . The presence of near-surface Pleistocene sediment with virtually no Holocene sediment cover at both sites suggests sporadic winnowing by fluctuating currents and/or erosion of modern sediment overburden, resulting in overconsolidated sediments.
\end{abstract}

\section{INTRODUCTION}

Heezen et al. (1966) proposed that the continental rise of eastern North America has been formed by the combined effects of turbidity currents and contour currents. Sediments deposited by contour currents have been called "contourites" (Hollister and Heezen, 1972) and exhibit bed forms ranging from small current ripples to large sediment waves or dunes with amplitudes of tens of meters and wavelengths of thousands of meters (Kennett, 1982). These currents also redeposit sediments as constructional ridges parallel to the current, and off the east coast of North America are most pronounced in middle Miocene and younger sediments (Tucholke and Mountain, 1979). The associated sediments exhibit thin bedding with sharp contacts between beds and are persistently laminated, well sorted, and graded.

DSDP Leg 93 drilling was performed in two areas: DSDP Site 603 sampled the boundary between the lower continental rise terrace and the lower continental rise hills; the upper continental rise was drilled at DSDP Sites 604 and 605 . Six consolidation-permeability tests were performed on samples collected from the contourite sediment sequence of the upper $131 \mathrm{~m}$ of Site 603 and one test was performed on the samples collected at Site 604 (4.42 $\mathrm{m}$ sub-bottom depth).

Previous studies (DSDP Legs 11-Hollister, Ewing, et al., 1972; 12-Laughton, Berggren, et al., 1972; 44Benson, Sheridan, et al., 1978; and 76-Sheridan, Gradstein, et al., 1983) have investigated the physical property characteristics of similar sediments; however, none of these studies has included the consolidation and permeability characteristics of contourite sediments. This chapter presents the results of consolidation and permeability tests and the associated physical properties of the samples tested.

${ }^{1}$ van Hinte, J. E., Wise, S. W., Jr., et al., Init. Repts. DSDP, 93: Washington (U.S. Govt, Printing Office),

2 Present address: Tetra Tech, Inc., 11820 Northup Way, Suite 100, Bellevue, WA 98005.

\section{TECHNIQUES}

Seven consolidation and permeability tests were performed on whole round core samples-using Anteus back pressure consolidometers modified for falling head permeability measurements-for sediments from DSDP Sites 603 and 604 (Table 1, Fig. 1). The general techniques for measuring consolidation and the advantages of back pressure consolidometers are discussed by Lambe (1951), Lowe et al. (1964), Lambe and Whitman (1969), and Bowles (1970).

Sample loading increments began at $6 \mathrm{kPa}$ and continued with daily increases of double the previous load to a maximum of $3200 \mathrm{kPa}$. Unloading was accomplished in decrements equivalent to one fourth the previous load. Falling head permeability measurements were performed after each daily loading.

The state of consolidation for a particular sample is determined by comparing the effective preconsolidation stress $\left(\sigma_{p}^{\prime}\right)$, calculated using the Casagrande Construction Technique (1936), to the effective overburden stress $\left(\sigma_{v o}^{\prime}\right)$, calculated assuming no excess hydrostatic pressure. For normally consolidated sediments, the present effective overburden stress is the maximum ever imposed, therefore $\sigma_{p}^{\prime}$ equals $\sigma_{v o}^{\prime}$. Overconsolidated sediments have been consolidated under a stress in excess of the present effective overburden stress, meaning that $\sigma_{p}^{\prime}$ is greater than $\sigma_{v o}^{\prime}$. The underconsolidated state implies that the sediments have not fully consolidated under the present effective overburden stress, hence, $\sigma_{p}^{\prime}$ is less than $\sigma_{v o}^{\prime}$.

The overconsolidation ratio, OCR, is the ratio of $\sigma_{p}^{\prime}$ to $\sigma_{v o}^{\prime}$, and numerically represents the state of consolidation: an OCR equal to 1 is a normally consolidated sediment, an OCR greater than 1 shows overconsolidation, and an OCR less than 1 shows underconsolidation.

The shape of the void ratio versus logarithm of vertical effective stress $\left(e-\log \sigma_{y}^{\prime}\right)$ curve can be characterized by the compression index, $C_{c}$, and the swell or rebound index, $C_{r}$. The compression index, which is a measure of the compressibility of the material, can thus be calculated:

$$
C_{c}=\frac{-\Delta e}{\Delta \log \sigma_{v}^{\prime}}
$$

for the virgin compression portion (i.e., linear) of the $e$-log $\sigma_{v}^{\prime}$ curve, where $\Delta e$ is the change in void ratio, and $\Delta \log \sigma_{v}^{\prime}$ is the change in vertical effective stress. The swell or rebound index can be similarly calculated for the rebound portion of the $e$-log $\sigma_{v}^{\prime}$ curve.

The void ratio at the effective preconsolidation stress, $e_{c}$, is interpolated from the $e$-log $\sigma_{v}^{\prime}$ curve at the effective preconsolidation stress. Similarly, the coefficient of permeability $(\mathrm{cm} / \mathrm{s})$ at the effective preconsolidation stress, $k_{c}$, can be interpolated from the permeability versus logarithm of vertical effective stress $\left(k-\log \sigma_{v}^{\prime}\right)$ curve (Table 1$)$. Permeability and void ratio calculated in this manner are intended to approximate the in situ values for the sediment. 
Table 1. Summary of sediment consolidation data.

\begin{tabular}{|c|c|c|c|c|c|c|c|c|c|c|c|}
\hline $\begin{array}{c}\text { Sample } \\
\text { (interval in } \mathrm{cm} \text { ) }\end{array}$ & $\begin{array}{l}\text { Sub-bottom } \\
\text { depth } \\
\text { (m) }\end{array}$ & $\begin{array}{c}\text { Initial } \\
\text { water } \\
\text { content, } \\
w_{0}(\%)^{\mathrm{a}}\end{array}$ & $\begin{array}{c}\text { Initial } \\
\text { void } \\
\text { ratio, } \\
e_{0}\end{array}$ & $\begin{array}{c}\text { Initial } \\
\text { porosity, } \\
(\%)\end{array}$ & $\begin{array}{c}\text { Compression } \\
\text { index, } \\
C_{c}\end{array}$ & $\begin{array}{l}\text { Swell } \\
\text { index, } \\
C_{r}\end{array}$ & $\begin{array}{c}\text { Effective } \\
\text { overburden } \\
\text { stress, } \\
\sigma_{v o}^{\prime}(\mathrm{kPa})\end{array}$ & $\begin{array}{c}\text { Effective } \\
\text { preconsolidation } \\
\text { stress, } \\
\sigma_{p}^{\prime}(\mathrm{kPa})^{\mathrm{b}}\end{array}$ & $\begin{array}{c}\text { Overconsolidation } \\
\text { ratio, } \\
\text { OCR }\end{array}$ & $\begin{array}{c}\text { Void } \\
\text { ratio, } \\
e_{c} \text { at } \sigma_{p}^{\prime c}\end{array}$ & $\begin{array}{l}\text { Coefficient of } \\
\text { permeability, } \\
k_{c} \text { at } \sigma_{p}^{\prime} \mathrm{d}^{2} \\
(\mathrm{~cm} / \mathrm{s})\end{array}$ \\
\hline $603-4-7,26-29$ & 131.46 & 78 & 2.267 & 69.39 & 0.55 & 0.11 & 787.6 & 36 & 0.05 & 1.83 & $2.74 \times 10^{-7}$ \\
\hline $603 C-3-4,142-145$ & 17.51 & 61 & 1.690 & 62.83 & 0.37 & 0.06 & 104.9 & 55 & 0.52 & 1.550 & $2.38 \times 10^{-7}$ \\
\hline $603 C-6-5,142-145$ & 47.81 & 64 & 1.788 & 64.13 & 0.68 & 0.12 & 282.3 & 440 & 1.56 & 1.413 & $7.60 \times 10^{-8}$ \\
\hline $603 C-8-3,142-145$ & 63.81 & 61 & 1.598 & 61.51 & 0.74 & 0.13 & 309.4 & 600 & 1.54 & 1.422 & $1.52 \times 10^{-7}$ \\
\hline $603 C-10-4,142-145$ & 83.21 & 56 & 1.601 & 61.55 & 0.75 & 0.12 & 522.5 & 620 & 1.19 & 1.427 & $6.38 \times 10^{-8}$ \\
\hline $603 C-13-1,145-148$ & 98.68 & 61 & 1.694 & 62.88 & 0.67 & 0.13 & 616.8 & 370 & 0.60 & 1.519 & $6.32 \times 10^{-8}$ \\
\hline $604-1-3,142-145$ & 4.42 & 35 & 0.955 & 57.04 & 0.25 & 0.05 & 39.4 & 72 & 1.83 & 0.902 & $1.36 \times 10^{-4}$ \\
\hline
\end{tabular}

${ }^{a} w_{0}=$ weight of water/weight of solids, salt corrected.

b $\sigma_{p}^{\prime}$, determined from Casagrande Construction Technique (1936).

$e_{c}$, determined from $e$-log $\sigma_{v}^{\prime}$ curve at $\sigma_{p}^{\prime}$.

$\mathrm{d}_{k_{c}}{ }_{c}$, interpolated from falling head permeability, $k$, versus $\log \sigma_{v}^{\prime}$ curve at $\sigma_{p}^{\prime}$.

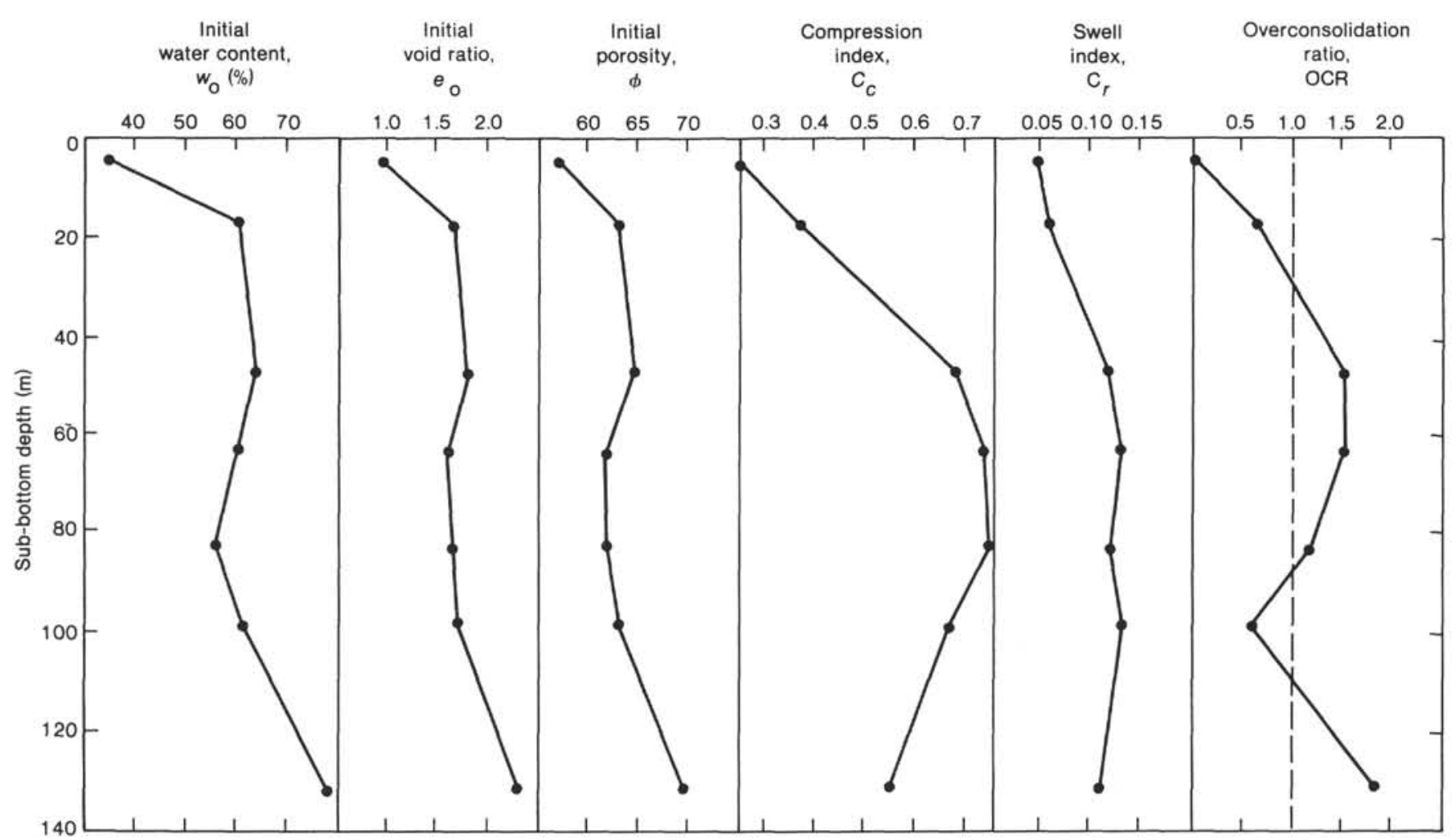

Figure 1. Plot of consolidation characteristics versus sub-bottom depth for all consolidation samples (data from Table 1).

The sediment physical properties were measured before consolidation was tested, using standard laboratory techniques, with all water content data corrected for a pore-water salinity of $35 \mathrm{ppt}$ (Hamilton, 1971). Shore-based laboratory measurements included water content, wet-bulk density, specific gravity of solids, grain size, wt. $\%$ calcium carbonate, undrained shear strength, and clay mineralogy (Table 2, Fig. 2). A Beckman air comparison pycnometer with helium as the gas medium was utilized for volumetric determinations. Vane shear strength measurements were made using a motorized vane at a shear rate of $60^{\circ} / \mathrm{min}$. (1.05 radians/min.) with a $1-\mathrm{cm}$-tall by $1-\mathrm{cm}$-diameter vane. Weight percent calcium carbonate was determined using a modified carbonate bomb technique (Schink et al., 1979). Grain size analysis was performed utilizing the pipette method for silts and clays (Folk, 1974). Sample preparation techniques for X-ray diffraction of the clay fraction $(<2 \mu \mathrm{m})$ followed those outlined by Jackson (1956) and modified by Hottman (1975). The Bradley form factor technique described by Scafe and Kunze (1971) was used to obtain relative percentages of clay mineral abundances.

\section{PHYSICAL PROPERTIES}

\section{Site 603 (Holes 603 and 603C)}

Three consolidation samples were collected at Hole 603 , but only one consolidation test was performed. Both Samples 603-12-3, 110-120 cm and 603-14-4, 140-150 cm were collected by rotary coring methods and were too highly disturbed to test; X-radiographs indicated these samples were severely cracked, though all sediment physical properties were determined (Table 2). The sediments consisted of greenish gray silty clays, containing average values of $0.2 \%$ sand, $27.3 \%$ silt, and $72.5 \%$ clay. The clay fraction consisted primarily of illite and smectite of approximately equal portions $(43 \%$ and $41 \%$ average, respectively) with minor amounts of kaolinite and chlo- 
Table 2. Summary of sediment physical properties.

\begin{tabular}{|c|c|c|c|c|c|c|c|c|c|c|c|c|}
\hline \multirow[b]{2}{*}{$\begin{array}{c}\text { Sample } \\
\text { (interval in } \mathrm{cm} \text { ) }\end{array}$} & \multirow{2}{*}{$\begin{array}{l}\text { Sub-bottom } \\
\text { depth } \\
\text { (m) }\end{array}$} & \multirow{2}{*}{$\begin{array}{c}\text { Bulk } \\
\text { density, } \\
\rho_{\mathrm{b}} \\
\left(\mathrm{Mg} / \mathrm{m}^{3}\right)\end{array}$} & \multirow{2}{*}{$\begin{array}{c}\text { Specific } \\
\text { gravity, } \\
G_{\mathrm{S}}\end{array}$} & \multirow{2}{*}{$\begin{array}{c}\text { Undrained } \\
\text { shear } \\
\text { strength, } \\
S_{\mathrm{u}}(\mathrm{kPa})\end{array}$} & \multirow{2}{*}{$\begin{array}{c}\text { Total } \\
\text { carbonate } \\
(\%)\end{array}$} & \multicolumn{3}{|c|}{ Grain size } & \multicolumn{4}{|c|}{ Clay mineralogy $(<2 \mu \mathrm{m})$} \\
\hline & & & & & & $\begin{array}{l}\text { Sand } \\
(\%)\end{array}$ & $\begin{array}{l}\text { Silt } \\
(\%)\end{array}$ & $\begin{array}{l}\text { Clay } \\
(\%)\end{array}$ & $\begin{array}{l}\text { Smectite } \\
(\%)\end{array}$ & $\begin{array}{l}\text { Illite } \\
(\%)\end{array}$ & $\begin{array}{l}\text { Kaolinite } \\
\qquad(\%)\end{array}$ & $\begin{array}{c}\text { Chlorite } \\
(\%)\end{array}$ \\
\hline $603-4-7,25-35$ & 131.46 & 1.58 & 2.77 & 5.22 & 18 & 0.35 & 24.85 & 74.81 & 40 & 43 & 9 & 8 \\
\hline $603-12-3,110-120$ & 270.35 & 1.84 & 2.76 & & 11 & 0.14 & 29.79 & 70.07 & 47 & 35 & 13 & 5 \\
\hline $603-14-4,140-150$ & 320.11 & 1.81 & 2.73 & & 14 & 0.26 & 27.22 & 72.52 & 35 & 52 & 9 & 4 \\
\hline $603 C-3-4,140-150$ & 17.51 & 1.67 & 2.77 & 11.86 & 28 & 1.82 & 23.38 & 74.80 & 14 & 59 & 10 & 17 \\
\hline $603 C-8-3,140-150$ & 63.81 & 1.69 & 2.76 & 52.25 & 10 & 0.14 & 27.14 & 72.72 & 34 & 46 & 14 & 6 \\
\hline $603 C-10-4,140-150$ & 83.21 & 1.72 & 2.75 & 80.33 & 16 & 0.41 & 29.54 & 70.05 & 44 & 35 & 17 & 4 \\
\hline $603 C-13-1,140-150$ & 98.68 & 1.70 & 2.77 & 54.86 & 14 & 0.22 & 26.12 & 73.65 & 41 & 42 & 14 & 3 \\
\hline $603 C-16-5,140-150$ & 133.40 & 1.77 & 2.74 & & 9 & 0.33 & 22.0 & 77.67 & 25 & 57 & 16 & 2 \\
\hline $604-1-3,140-150$ & 4.42 & 1.94 & 2.76 & 15.02 & 9 & 8.94 & 42.98 & 48.08 & 7 & 60 & 11 & 22 \\
\hline
\end{tabular}

a Laboratory carbonate bomb tests.

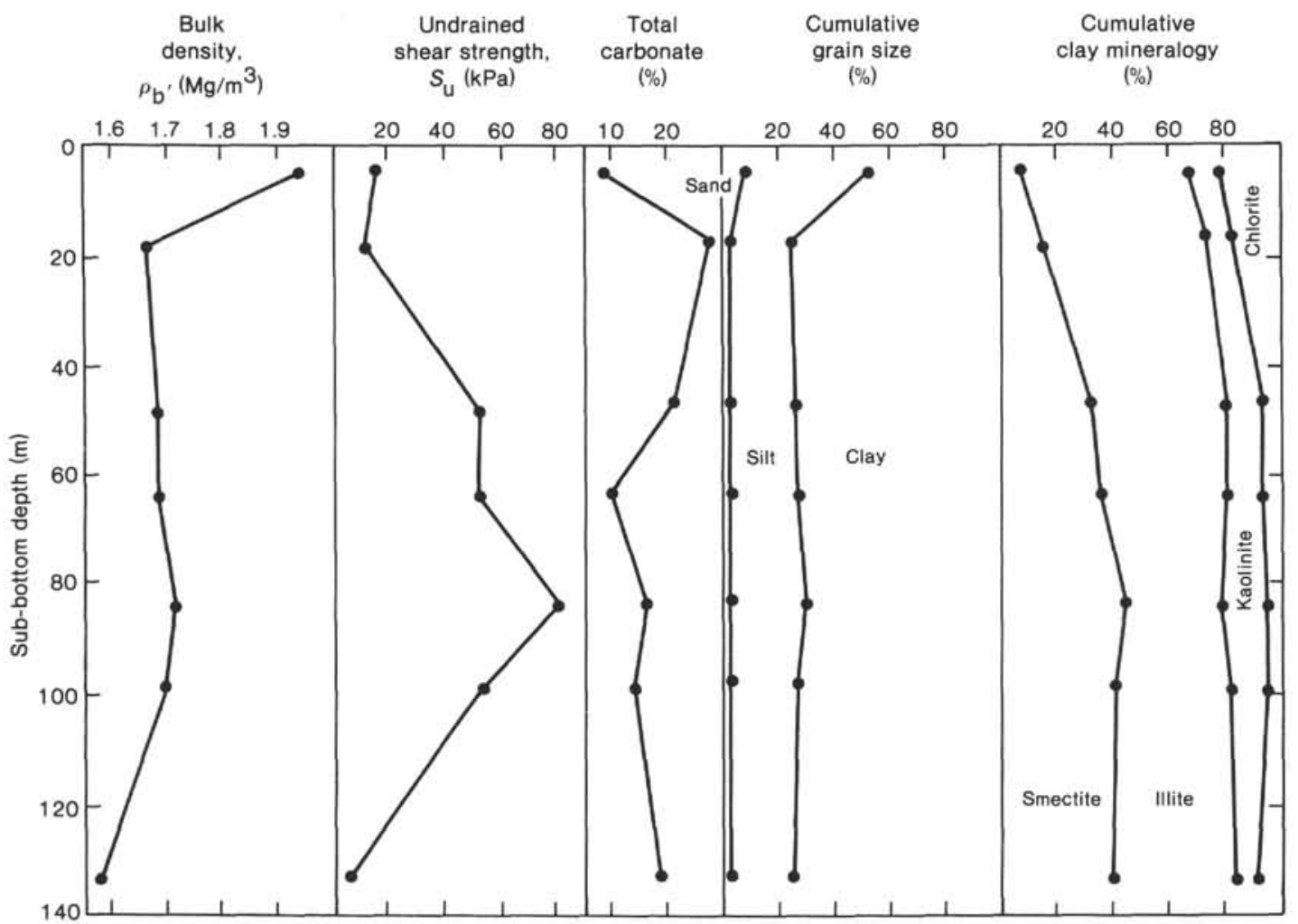

Figure 2. Plot of physical properties versus sub-bottom depth for all consolidation samples (data from Table 2).

rite ( $10 \%$ and $6 \%$ average, respectively). Sample 603 4-7, 25-35 cm exhibited high initial water content and porosity and low wet-bulk density. X-radiographs of this sample showed longitudinal cracks, indicative of gas expansion tracks. Weight percent calcium carbonate averaged $14 \%$ for the three samples.

Six greenish gray silty clay samples were collected for consolidation testing from Hole 603C (Table 2). X-radiographs indicated severe cracking in Sample 603C-16-5, $140-150 \mathrm{~cm}$, thus no consolidation-permeability test was performed for this sample. In addition, Sample 603C$3-4,140-150 \mathrm{~cm}$ showed evidence of drag marks created by a loose O-ring in the core liner, which was later found in Section 603C-2-5. A sample from this section was tested, but the amount of disturbance caused by the O-ring could not be determined from the X-radiograph. The sedi- ments contained average values of $0.5 \%$ sand, $25.7 \%$ silt, and $73.8 \%$ clay. The clay fraction was rich in illite and smectite (48\% and $32 \%$ average, respectively) with lesser amounts of kaolinite and chlorite $(14 \%$ and $6 \%$ average, respectively). Bulk density and undrained shear strength showed slightly increasing trends with depth, whereas wt. $\%$ calcium carbonate, initial porosity, and water content tended to decrease with depth. Sample 603C$13-1,140-150 \mathrm{~cm}$ did not follow the above-mentioned trends and exhibited minor radial cracks that may have been a result of gas expansion or core disturbance.

\section{Site 604 (Hole 604)}

One consolidation sample, 604-1-3, 140-150 cm, was collected by rotary coring methods from Site 604 at a sub-bottom depth of $4.42 \mathrm{~m}$ (Table 2, Fig. 2). This dark 

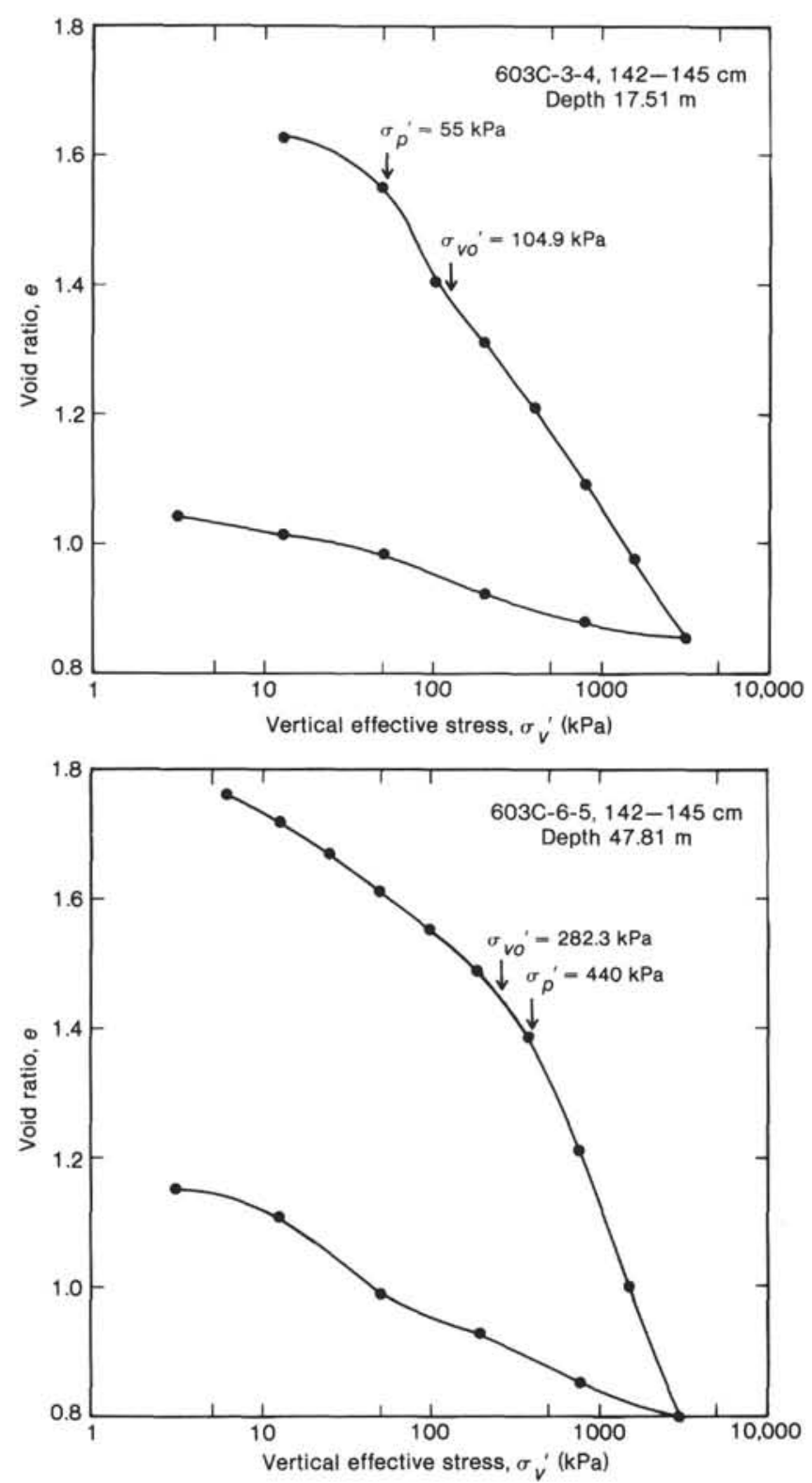

Figure 3. Void ratio versus logarithm of vertical effective stress ( $e-\log$ $\left.\sigma_{v}^{\prime}\right)$ curves for Site 603 .

greenish gray, sandy silty clay contained considerably higher sand and silt contents than did the Site 603 sediments. The clay fraction consisted of predominantly illite with lesser amounts of chlorite, kaolinite, and smectite, respectively. In addition, wet-bulk density was much higher, and both water content and initial porosity were much lower for this near-surface sample than for Site 603 sediments.

\section{CONSOLIDATION AND PERMEABILITY CHARACTERISTICS}

All consolidation test results are plotted as $e$-log $\sigma_{v \text {. }}^{\prime}$ curves (Figs. 3-6). In addition, the sample consolidation characteristics are plotted with depth (Fig. 1). The physical property characteristics of the consolidation samples are plotted at the same scale for ease of comparison (Fig. 2).
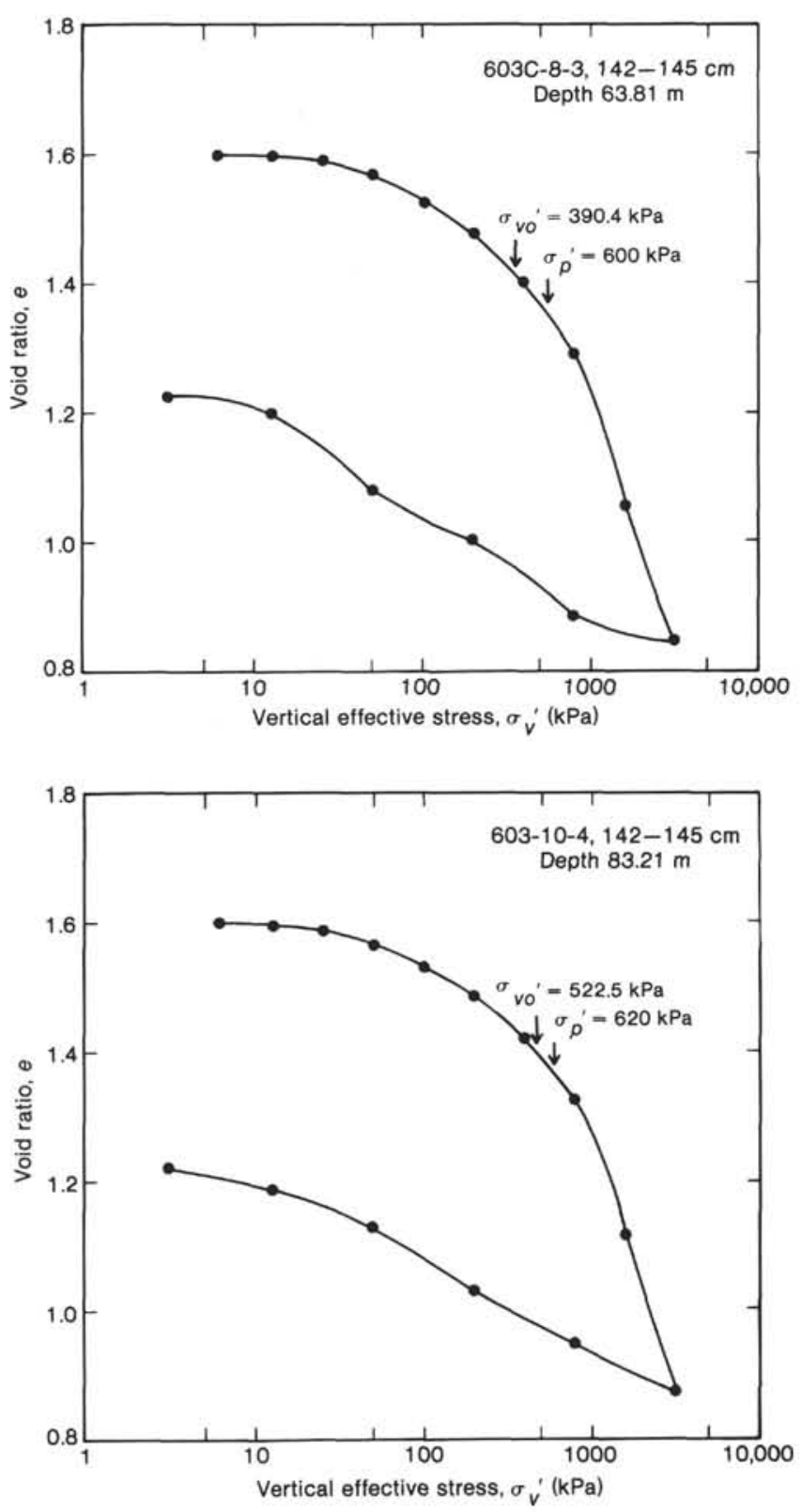

Figure 4. Void ratio versus logarithm of vertical effective stress ( $e-\log$ $\left.\sigma_{v}^{\prime}\right)$ curves for Site 603.

\section{Site 603 (Holes 603 and 603C)}

Site 603 was drilled between the lower continental terrace and rise hills, some 270 nautical miles (n. mi.) east of Cape Hatteras, North Carolina. Consolidation samples were obtained from the Blake Ridge Formation, consisting of hemipelagic greenish gray muds. Seismic records indicate a series of rising "anti dune-like" sediments in this region (see Site 603 chapter, this volume). This formation consists of hemipelagic sediments reworked by the Western Boundary Undercurrent. Current action tends to rework and pile the sediments to form the continental rise hills along the U.S. east coast; these sediments have generally been termed "contourite" sediments (Heezen et al., 1966; Hollister and Heezen, 1972).

Six consolidation tests were performed for Site 603 (Hole 603, $131.46 \mathrm{~m}$; Hole 603C, 17.51, 47.81, 63.81, 

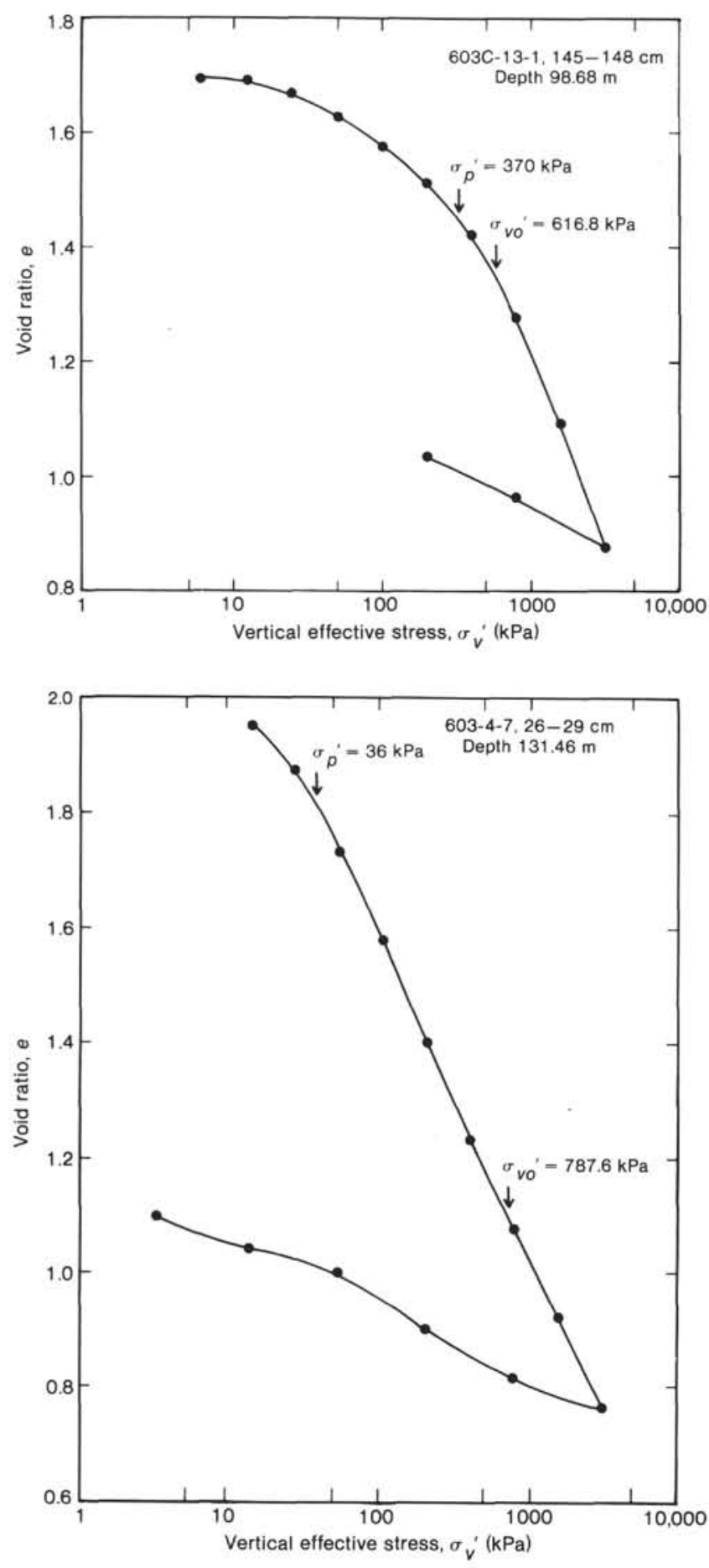

Figure 5. Void ratio versus logarithm of vertical effective stress ( $e-\log$ $\left.\sigma_{v}^{\prime}\right)$ curves for Site 603.

83.21 , and $98.68 \mathrm{~m}$ sub-bottom depth) on samples consisting of greenish gray silty clays (Table 2 ). The consolidation test results are plotted as void ratio versus effective stress, $e-\log \sigma_{v}^{\prime}$ (Figs. 3-5). When the effective preconsolidation stresses are plotted on a graph of effective overburden stress versus sub-bottom depth, the near-surface sample $(603 \mathrm{C}-3-4,142-145 \mathrm{~cm})$ and the two deepest samples (603C-13-1, 145-148 cm and 603-4-7, 26-29 cm) appear to be underconsolidated (Fig. 7). The compres-

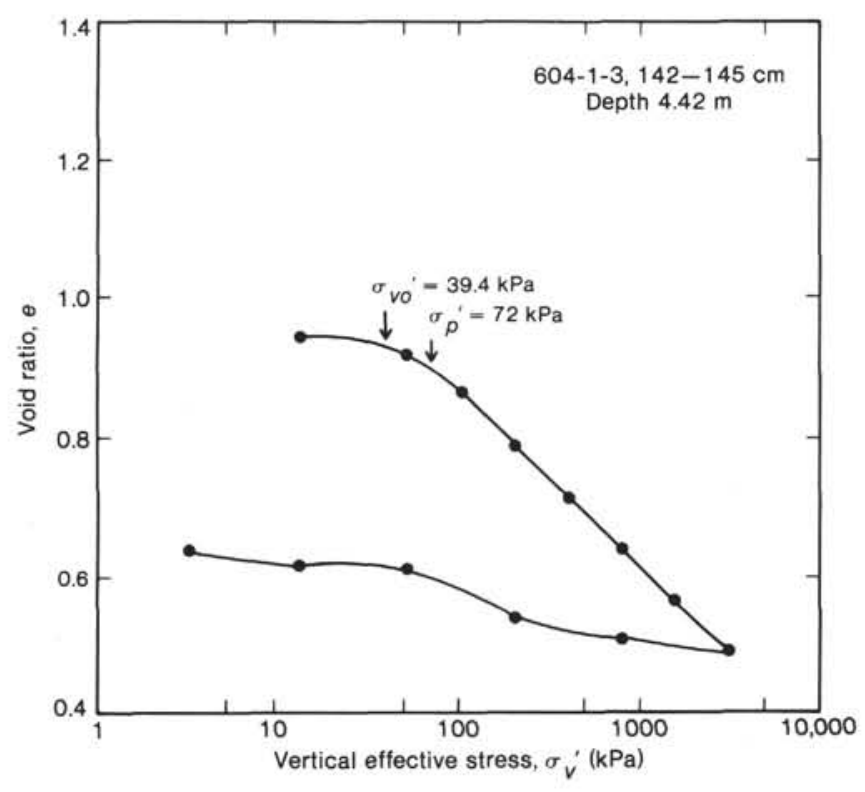

Figure 6. Void ratio versus logarithm of vertical effective stress ( $e-\log$ $\left.\sigma_{v}^{\prime}\right)$ curves for Site 604 .

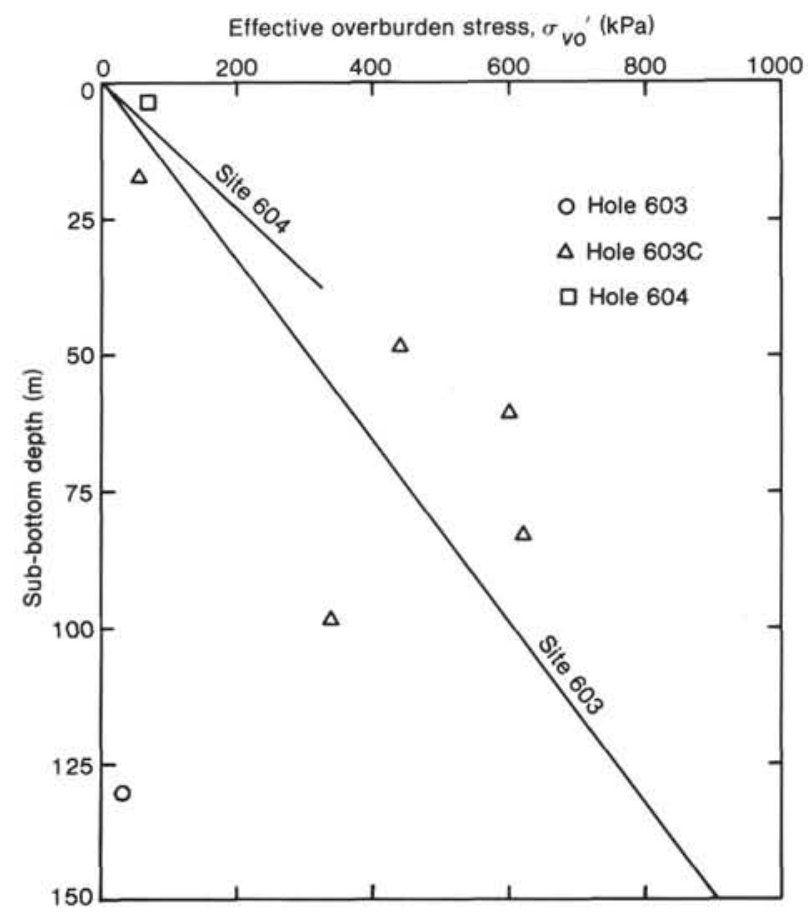

Figure 7. Plot of effective overburden stress $\left(\sigma_{v o}^{\prime}\right)$ versus sub-bottom depth, with effective preconsolidation stress $\left(\sigma_{p}^{\prime}\right)$ data from consolidation test results shown as discrete points. Those points that fall to the left of the respective site line are underconsolidated, those to the right are overconsolidated.

sion indexes for these samples are low, with the near-surface sample exhibiting the lowest value measured (Table 1). The mid-depth samples (603C-6-5, 42-145 cm; 603C-8$3,142-145 \mathrm{~cm}$; and $603 \mathrm{C}-10-4,142-145 \mathrm{~cm}$ ) are overconsolidated, with the overconsolidation ratio decreasing with depth. These samples also exhibit the highest compression indices, $C_{c}$. 
All the $e-\log \sigma_{v}^{\prime}$ curves for samples from this site exhibit distinct breaks to the virgin curve, except Samples 603C-3-4, 142-145 cm and 603-4-7, 26-29 cm (17.51 and $131.46 \mathrm{~m}$ sub-bottom depth, respectively), which exhibit near-linear virgin curves (Figs. 3 and 5). This behavior is typical of a thoroughly remolded specimen (Schmertman, 1955). Remolding tends to obliterate the stress history and aging effects and provides slightly lower compression indexes than for undisturbed specimens. The compression indexes were slightly lower for Sample 6034-7, 26-29 cm, suggesting a greater degree of disturbance (Table 1). Sample 603C-3-4, 142-145 cm exhibited a slight break to a near-linear curve. The lower compression index and shape of the $e-\log \sigma_{v}^{\prime}$ curve is consistent with a large degree of disturbance caused by the errant O-ring, which was suggested from X-radiograph interpretations. Holes 603 and 604 were rotary cored, whereas Hole 603C samples were collected by hydraulic piston core to Core 11. The extended core barrel (XCB) was utilized from Core 12 to the total depth of Hole $603 \mathrm{C}$. Sample recovery was severely reduced for Cores 12 and 13 .

Permeability values $\left(k_{c}\right)$ for the Site 603 samples were quite uniformly low and ranged from $2.74 \times 10^{-7} \mathrm{~cm} / \mathrm{s}$ to $6.32 \times 10^{-8} \mathrm{~cm} / \mathrm{s}$ (Table 1, Fig. 7). The values tend to cluster, indicating the constancy of estimated in situ permeability $\left(k_{c}\right)$ and void ratio $\left(e_{c}\right)$ with depth.

\section{Site 604 (Hole 604)}

Site 604 was rotary drilled on the upper continental rise about $100 \mathrm{n}$. mi. southeast of Atlantic City, New Jersey. This site is part of the "New Jersey Transect," which consists of four proposed core holes located along a single seismic reflection profile over the U.S. east coast continental shelf, margin, and upper rise. One consolidation sample was tested (604-1-3, 142-145 cm) from the uppermost section (4.42 m sub-bottom depth) of the Blake Ridge Formation. Seismic reflection records show the uppermost Unit 1 contains transparent portions with some parallel, fairly even reflectors (Site 604 chapter, this volume).

The single consolidation sample tested from this site consisted of dark grayish olive green, slightly sandy silty clay (Table 2). Consolidation test results show this sample to be overconsolidated (Figs. 6 and 7). However, previous drilling on the New Jersey Transect (Scholle, 1980) indicated the presence of firm, exposed Pleistocene silty clay in this region. The permeability value $\left(k_{c}\right)$ for Sample $604-1-3,142-145 \mathrm{~cm}$ is equal to $1.36 \times 10^{-4} \mathrm{~cm} / \mathrm{s}$ and reflects the high percentage of sand and silt present (Tables 1 and 2, Fig. 8).

\section{DISCUSSION}

The process of gravitational consolidation is the phenomenon by which the void ratio of a given sediment is decreased by the addition of overburden in the form of the weight of the overlying sediments. Underconsolidated sediments exhibit pore-water pressures in excess of hydrostatic or steady state and develop as a result of factors that impede the flow of water through the sediment or induce stresses that contribute to the development of excess pore-water pressures; these factors include: (1) high

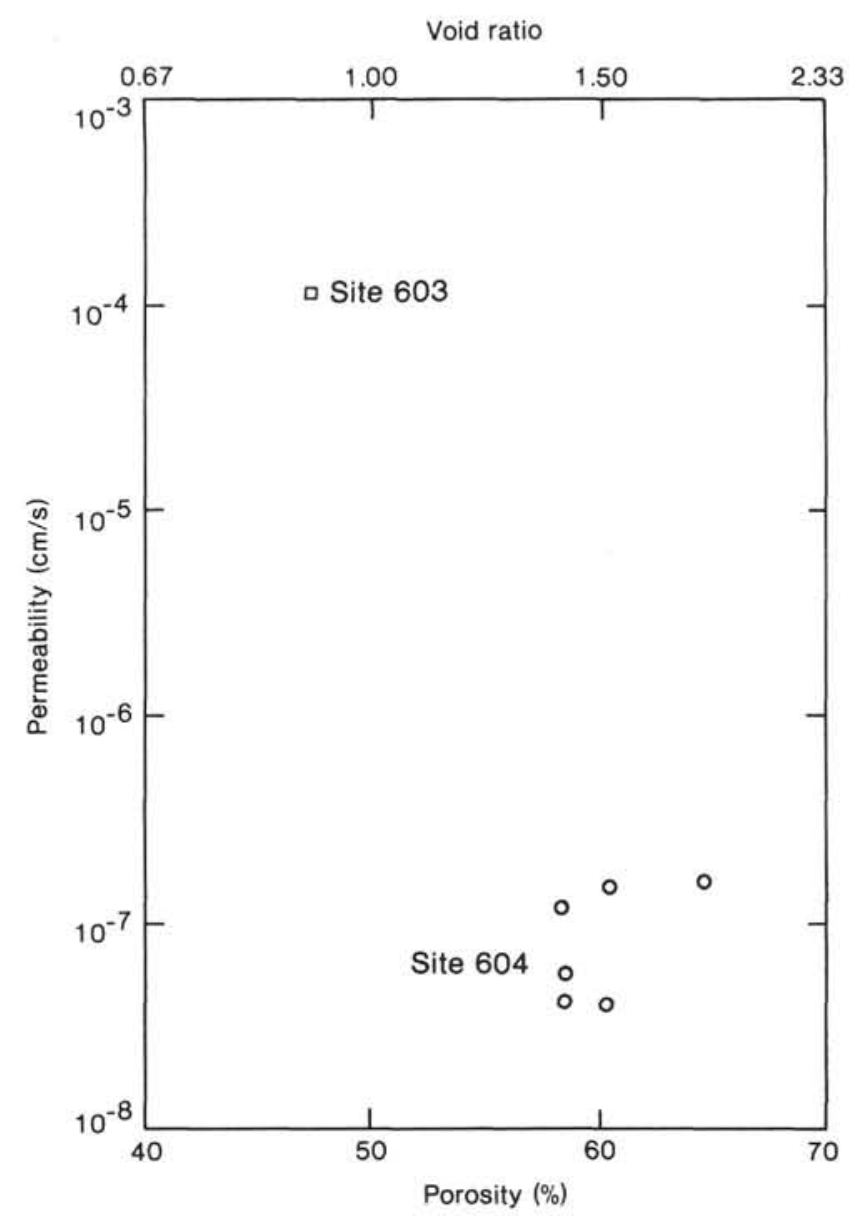

Figure 8 . Void ratio $\left(e_{c}\right)$ and porosity $(\phi)$ versus permeability $\left(k_{c}\right)$. Note the low permeability values and clustering for Site 603 .

sediment accumulation rates; (2) low permeabilities; (3) laterally applied stresses; and (4) physiochemical interparticle bonding and cementation. Overconsolidation can result from a combination of factors that include: (1) cementation; (2) slow ratios of sediment accumulation; and (3) erosion of overburden.

The apparent state of underconsolidation for consolidation Samples 603C-3-4, 142-145 cm, 603-4-7, 26-29 $\mathrm{cm}$, and $603 \mathrm{C}-13-1,145-148 \mathrm{~cm}$ appears to be a result of core disturbance. This has led to low values for estimated effective preconsolidation stresses, $\sigma_{p}^{\prime}$, and compression indexes for these samples. Disturbance seems to be a result of the coring process and degassing of porewater gases. Disturbance effects resulting from ebullition of pore-water gas were observed visually while trimming the consolidation samples and by X-radiography. Sample $603-4-7,26-29 \mathrm{~cm}$ was severely disturbed by degassing. The extremely low shear strength value $(5.22 \mathrm{kPa})$ and very high initial void ratio (2.267) of this sample, collected at a depth of $131 \mathrm{~m}$, is further evidence of disturbance. Sample 603-4-7, 26-29 cm was collected below horizon $\mathrm{P}^{\prime}$, which was encountered at $121 \mathrm{~m}$ subbottom depth.

Sample 603C-3-4, 142-145 cm shows a distinct break in the virgin curve (Fig. 3). This near-surface sample (17.51 m sub-bottom depth) shows underconsolidation, 
but this is a result of mechanical disturbance caused by an O-ring that was dragged through the core.

Sediments collected at Site 603 from 47 to $83 \mathrm{~m}$ subbottom depth are slightly overconsolidated. The hydraulic piston corer recovered relatively undisturbed sediments over this region. Furthermore, the sediments were not disturbed by degassing upon release of hydrostatic pressure with core recovery. X-radiography confirmed this lack of disturbance. It is not uncommon to have OCR values in excess of 1 for near-surface samples (Skempton, 1970; Bryant et al., 1981). This apparent state of overconsolidation can arise from the internal strength of the sediments denoted as "origin cohesion."

Long, isolated ridges composed of thick piles of hemipelagic sediments have been recognized from seismic reflection profiles over the deep-sea floor. These ridges have been closely related to known deep-water circulation patterns of the North Atlantic (Johnson and Schneider, 1969; Jones et al., 1970). Direct current measurements of over $40 \mathrm{~cm} / \mathrm{s}$ have been made, with common velocities in the range of 10 to $20 \mathrm{~cm} / \mathrm{s}$ (Luyten, 1977). The higher-velocity currents are capable of transporting and depositing a range of fine-grained sediments (Einstein and Krone, 1962; Partheniades et al., 1969). The effects of longterm current erosion and/or redeposition of these finegrained sediments at Site 603 would produce overconsolidated sediments. Constant resuspension and winnowing of sediments would at times remove overburden or reduce sedimentation rates.

Sample 604-1-3, 142-145 cm had the highest OCR value measured for the sediments tested. In addition, this sandy silty clay had the lowest coefficient of consolidation and initial void ratio. Pleistocene sediments with no Holocene sediment cover were encountered at Site 604 . The sediments at this site showed much evidence of sediment redeposition and mass movement (Site 604 chapter, this volume). Concentrations of heavy minerals suggested sporadic winnowing by fluctuating bottom currents (see Lithostratigraphy section of Site 604 chapter, this volume). The alternating silt and clay layers of lithologic Unit I are also compatible with the expected sedimentary structures of contourites. The overconsolidated state appears to result from removal of modern sediment overburden caused by erosion.

\section{CONCLUSIONS}

Consolidation, permeability, and physical property testing has been performed on core samples obtained at the boundary between the lower continental rise terrace and the lower continental rise hills and on the upper continental rise. Two general types of sediments were encountered: hemipelagic muddy contourites and hemipelagic Pleistocene sandy silty muds.

The hemipelagic contourite sediments are overconsolidated, as would be expected for a winnowed sediment deposit. Sporadic winnowing by bottom currents results in redeposited sediment packages. Additionally, periods of erosion may result from periods of increased current action. Core and gas disturbance has resulted in an apparent state of underconsolidation for three samples and these results are not considered to be indicative of in situ conditions.
The surface hemipelagic sandy silty clay sample collected along the New Jersey Transect is overconsolidated. No conclusive results can be stated based on the evidence of a single consolidation test, though removal of sediments by fluctuating bottom currents can account for the overconsolidated nature of the sediment. In addition, the high sand and silt contents and relatively high undrained shear strength are consistent with the overconsolidated state of the materials.

\section{ACKNOWLEDGMENTS}

The author wishes to thank Drs. Elliot Taylor and William Bryant for their invaluable assistance in preparing this manuscript.

\section{REFERENCES}

Benson, W. E., Sheridan, R. E., et al., 1978. Init. Repts. DSDP, 44: Washington (U.S. Govt. Printing Office).

Bowles, J. E., 1970. Engineering Properties of Soils and Their Measurement: New York (McGraw-Hill).

Bryant, W. R., Bennett, R. H., and Katherman, C. F., 1981. Shear strength, consolidation, porosity, and permeability of oceanic sediments. In Emiliani, C. (Ed.), The Sea: The Oceanic Lithosphere (Vol. 7): New York (John Wiley \& Sons), 1555-1615.

Casagrande, A., 1936. The determination of the pre-consolidation load. Proc. Int. Conf. Soil Mech. Found. Eng. (Cambridge), 3:60-64.

Einstein, H. A., and Krone, R. B., 1962. Experiments to determine modes of cohesive sediment transport in salt water. J. Geophys. Res., 67:1451-1461.

Folk, R. L., 1974. Petrology of Sedimentary Rocks: Austin, Texas (Hemphill Publ. Co.).

Hamilton, E. L., 1971. Prediction of in-situ acoustic and elastic properties of marine sediments. Geophysics, 36(2):266-284.

Heezen, B. C., Hollister, C. D., and Ruddiman, W. F., 1966. Shaping of the continental rise by deep geostrophic contour currents. Science, 152:502-508.

Hollister, C. D., Ewing, J. I., et al., 1972. Init. Repts. DSDP, 11: Washington (U.S. Govt. Printing Office).

Hollister, C. D., and Heezen, B. C., 1972. Geological effects of ocean bottom current. In Gordon, A. L. (Ed.), Studies in Physical Oceanography (Vol. 2): New York (Gordon \& Breach), 37-66.

Hottman, W. E., 1975. Areal distribution of clay minerals and their relationship to physical properties, Gulf of Mexico [Masters thesis]. Texas A\&M University, College Station, Texas.

Jackson, M. L., 1956. Soil Chemical Analysis-Advanced Course: Madison, Wisconsin (M. L. Jackson, Department of Soil Science, University of Wisconsin).

Johnson, G. L., and Schneider, E. D., 1969. Depositional ridges in the North Atlantic. Earth Planet. Sci. Lett., 6:416-422.

Jones, E. J. W., Ewing, M., Ewing, J. I., and Eittreim, S. L., 1970. Influences of Norwegian Sea overflow water on sedimentation in the northern Atlantic and Labrador Sea. J. Geophys. Res., 75:16551680.

Kennett, J. P., 1982. Marine Geology: Englewood Cliffs, New Jersey (Prentice-Hall, Inc.)

Lambe, T. W., 1951. Soil Testing for Engineers: New York (John Wiley \& Sons).

Lambe, T. W., and Whitman, R. V., 1969. Soil Mechanics: New York (John Wiley \& Sons).

Laughton, A. S., Berggren, W. A., et al., 1972. Init. Repts. DSDP, 12: Washington (U.S. Govt. Printing Office),.

Lowe, J., Zaccheo, P. F., and Feldman, H. S., 1964. Consolidation testing with back pressure. J. Soil Mech. Found. Div. Am. Soc. Civ. Eng., 90:69-86.

Luyten, J. R., 1977. Scales of motion in deep Gulf Stream and across the Continental Rise. J. Mar. Res., 35:49-74.

Partheniades, E., Cross, R. H., and Ayora, A., 1969. Further results on the deposition of cohesive sediments. Proc. 11th Conf. Coastal Engineering, pp. 723-742.

Scafe, D. W., and Kunze, G. W., 1971. A clay mineral investigation of six cores from the Gulf of Mexico. Mar. Geol., 10:69-85.

Schink, J. C., Stockwell, J. H., and Ellis, R. A., 1979. An improved device for gasometric determination of carbonate in sediment. $J$. Sed. Petrol., 49:651-653. 
Schmertman, J. M., 1955. The undisturbed consolidation behavior of clay. Am. Soc. Civ. Eng. Trans., 120:1201-1227.

Scholle, P. A., 1980. Geologic studies of the COST NO. B-3 well, United States Mid-Atlantic Continental Slope area. U.S. Geol. Surv. Circ. 833.

Sheridan, R. E., Gradstein, F. M., et al., 1983. Init. Repts. DSDP, 76: Washington (U.S. Govt. Printing Office).

Skempton, A. W., 1970. The consolidation of clays by gravitational compaction. Geol. Soc. London, 125:373-411.
Tucholke, B. E., and Mountain, G. S., 1979. Seismic stratigraphy, lithostratigraphy, and paleosedimentation patterns in the North American Basin. In Talwani, M., Hay, W., and Ryan, W. B. F. (Eds.), Deep Drilling Results in the Atlantic Ocean: Continental Margins and Paleoenvironment: Washington (Am. Geophys. Union), Maurice Ewing Series, 3:58-86.

Date of Initial Receipt: 3 October 1984 Date of Acceptance: 21 June 1985 